The Vampyre and Ernestus Berchtold; or, The Modern Oedipus Collected Fiction of John William Polidori

In 1816, John William Polidori travelled to Geneva as Byron's personal physician; there he met Mary and Percy Shelley and took part in the most famous house party in literary history. To pass the time in 'a wet, ungenial summer,' the travellers took to writing ghost stories. Byron wrote his Faustian drama Manfred (1817); Mary Shelley wrote her masterpiece, Frankenstein; or The Modern Prometheus (1818). Polidori appropriated an unfinished story by Byron and turned it into The Vampyre (1819). Polidori's tale, with its nightmarish atmosphere and seductive, aristocratic villain, was a scandalous success; the fact that it was originally published, without Polidori's knowledge, under Byron's name, didn't hurt. All the most famous vampires of popular culture, from Stoker's Dracula to Anne Rice's Lestat, descend from Polidori's Byronic prototype.

Polidori also contributed an original novel to the ghost-story project: Ernestus Berchtold; or, The Modern Oedipus (1819). Polidori's novel explores the incest theme common to such Romantic works as Manfred, Percy Shelley's Alastor, and M.G. Lewis's The Monk, and combines this Gothic material with a historical account of Napoleon's 1798 invasion of Switzerland, one of the key moments in the political evolution of Romanticism.

This edition includes the extensive revisions Polidori made for a projected second edition of The Vampyre. Ernestus Berchtold is reprinted for the first time in the 174 years since its initial publication. The critical introductions and explanatory annotations place the two works in their biographical, historical, and literary contexts. Appendices include a new edition of the fragment by Byron on which The Vampyre was based, and a fragmentary tale by Polidori, never before published, which shows him exploring new literary directions after being fired by Byron and returning to England in disgrace.

D.L. MACDONALD is assistant professor in the Department of English, University of Calgary, author of Poor Polidori: A Critical Biography of the Author of The Vampyre, and co-editor of The Writer and Human Rights and Flaws in the Pattern: Human Rights in Literature. KATHLEEN SCHERF is associate professor of English, University of New Brunswick. Her scholarly edition of The Collected Poetry of Malcolm Lowry appeared in 1992. She and D.L. Macdonald have forthcoming an edition of Shelley's Frankenstein, and her student writing textbook will appear in 1994. She is the editor of Studies in Canadian Literature. 

Edited and Introduced by

D.L. Macdonald and Kathleen Scherf

The Vampyre and Ernestus Berchtold; or, The Modern Oedipus:

\section{Collected Fiction of}

John William Polidori

UNIVERSITY OF TORONTO PRESS

Toronto Buffalo London 
() University of Toronto Press Incorporated 1994

Toronto Buffalo London

Printed in Canada

Reprinted in 2018

ISBN 0-8020-0506-3 (cloth)

ISBN 978-0-8020-7465-2 (paper)

$(0)$

Printed on acid-free paper

\section{Canadian Cataloguing in Publication Data}

Polidori, John William, 1795-1821

The vampyre and Ernestus Berchtold; or,

The modern Oedipus

ISBN 0-8020-0506-3 (bound) ISBN 978-0-8020-7465-2 (paper)

I. Macdonald, David Lorne, 1955- II. Scherf, Kathleen, 1960- . III. Title. IV. Title:

Ernestus Berchtold. v. Title: The modern Oedipus.

PR5187.P5V36 $1994 \quad 823^{\prime} \cdot 7 \quad$ C93-095000-3 
For our parents:

George and Helga Scherf

and

Doreen Macdonald Zaharuk and Peter Zaharuk 
